\title{
Empirical Evidence Impact of Interest Rate on Loan Repayment of Microfinancial Institution in Tanzania
}

\author{
Ali Othman Abbas, Zhang Honghui \\ School of Accounting, Jiangxi Unversity of Finance and Economics, Nanchang, China \\ Email address: \\ abbasal14@hotmail.com (A. O. Abbas),danordio@163.com (Zhang Honghui) \\ To cite this article: \\ Ali Othman Abbas, Zhang Honghui. Empirical Evidence Impact of Interest Rate on Loan Repayment of Microfinancial Institution in \\ Tanzania. International Journal of Business and Economics Research. Vol. 5, No. 5, 2016, pp. 143-148. doi: 10.11648/j.ijber.20160505.12
}

Received: August 1, 2016; Accepted: September 1, 2016; Published: September 6, 2016

\begin{abstract}
Microfinance nowadays is about drawing the benefits of modern entrepreneurship downward to those with low incomes relatively than endorse alternatives to free enterprise; "...it is a component of the post-Washington Consensus [30]" also not a substitute to the prevailing attitude. We adopted descriptive assessment techniques, the data were collected through interviewing or administering a questionnaire to a sample of 400 respondents, and analyzed by using SPSS software. There was strong negative correlation between multiple loans and positive corelation between business capacity and extent of higher interest rates charged. The study recommended that the business owner should focus on the level of the business capacity with loan proposed to be taken and make the comparisons of the daily business revenues operation and not the capital of the business initiatives.
\end{abstract}

Keywords: Microfinance Institutions, Interest Rates, Multiple Loan, Business Capacity

\section{Introduction}

Since the 1980's microfinance has turned out to be an essential constituent of development, deficiency reduction as well as economic regeneration plans around the world. By near the beginning of the twenty-first century tens of millions of citizens in more than 100 countries were admittance of services from formal and semi formal microfinance institutions (MFIs). It has turned out to be a huge global industry connecting large figures of governments, banks, aid agencies, nongovernmental organizations (NGO's), cooperatives as well as consultancy firms and honestly utilized hundreds of thousands of branch-level staff. To a great extent of the original animation about microfinance centered in Bangladesh's much lauded Grameen Bank, which talked on the transformation of economic and social structures through microenterprise loans and group formation. It propounded a 'bottom-up' approach that made the social mobilization of marginalized communities, and particularly women, a main focus [10]. Many MFIs provide advance payment along with diminishing the administrative costs (otherwise shift them to customers) of congregation information, agreement design in addition to enforcement of credit transactions, together with loan revival. In excess of time, the microfinance segment has turned out to be less the domain of NGOs and non profit and more the domain of commercial organizations. According to [6] nearly $70 \%$ of the MFIs customers are amongst the poorest when they acquire the initial loan, although several observers question this argument in conditions of the financial size of the business. In Bangladesh, the Grameen Bank and the Bangladesh Rural Advancement Committee (BRAC) have payout of over US\$4.7 billion and US\$2.2 billion respectively [11]. On the other hand, the phenomenal growth of the segment has brought away the concern of poor administration and insufficient corporate governance in the middle of MFIs [17].

Microfinancial services have produced significant interest along with academic, donors and improvement practitioners as a substitute to the acknowledged disappointment of government countryside credit support to accomplish lowincome households $[12,13]$. The disappointments are accredited to reasons such as urban-biased credit allotment, upper transaction expenses, interest rate limitations, high default rates along with fraudulent practices. The reasons for poor loan improvement are associated with inappropriate plan facial appearance, leading to inducement troubles, and politicization that completed borrower's inspection credit as 
political charity [19]. This dissatisfaction developed as a set of inventive financial institutions in several areas of the world which commence to thrive along with drawing attention, particularly in Bolivia, Bangladesh and Indonesia. These microfinance institutions (MFIs) allocate a loyalty to serving clients that have been expelled from the formal banking sector.

The improvement of the microfinance segment is based on the hypothesis that the poor have the ability to execute income-generating financial viable activities other than are limited by deficiency in access along with insufficient stipulation of investments, credit and indemnity conveniences. This approach, what's more, splits from the directed credit tactic by dropping the government participation and as a result paying close consideration to incentives that drive efficient performance [23]. The developments of microfinance services have been found on a prototype rescue form that is judged the most excellent response to capture financial needs of the poor in various socioeconomic and institutional systems. However, after two decades of experience, a better understanding of financial service preferences and behaviors of the poor and poorest is still required to develop the capacity of microfinance scheme to concentrate concerning welfare implications of MFIs [24, $20,9,26]$. MFIs are mostly registered as NGOs which are not generally included under the financial regulation followed by the central banks and do not have a legal charter to engage in financial intermediation. In many countries, deposit taken from the public is an activity restricted to licensed financial institutions only. Most of the MFIs are dependent on subsidies and are unable to operate profitably enough to pay a commercial cost for a large portion of their funds $[5,10]$. This restricted status has prohibited most of the MFIs from accessing deposits from the public or engaging in any type of banking operation, such as providing savings services for the poor, which is a way of obtaining a long term source of capital at a reduced cost. There are no other possible avenues for these institutions to raise resource to sustainably deliver an increasing variety of financial service to the poor.

In this scenario, adequate regulations may allow these institutions to attract deposits from the public which may in turn allow them to grow in a sustainable way. Regulations may also bring about greater linkages with the bank sectors, an improved operating network and higher standards of control and reporting. The nature of contract between depositors and financial organizations could also provide windows for opportunistic behavior by the financial institution which justifies the needs for regulations. However, one needs to be definite that excessive reguations will not lead to repression of innovation and flexibility in providing services, both of which are imperative to the growth of MFIs, whether the regulatory mechanisms facilitate existing providers in enlarging their activities or not and to what extent they encourage the entry of new providers in the sector. The most interesting for example in Indonesia and Phillipines show the availability of legal charter with low capital requirements has brought private rural banks into the microfinance sectors. Not only that, some governments are concerned about higher interest rates, for example, in Latin America experience shows that non involvement by government has helped the MFIs immensely in their early stages $[5,10]$ but also had legally permissible lower levels of interest rates which were not enough for sustainable MFIs operation and which compelled them to operate as nongovernmental organizations (NGOs). Governments have seen the enhanced demand for higher interest rates loans and these have become a non issue in the licensing of MFIs and also regulate these institutions to protect depositor's interest, particularly in case of those MFIs which are already taking deposit, for example in the case of Bagladesh many poor peoples lost their savings due to the incompetence or fraud of unregulated and little known institutions [33].

Most of the governments which have followed a laissez faire approach to MFI's so far have been changing recently, because they are considering this as an opportunity for them to engage with MFIs, mainly due to the high political profile of these institutions. Since governments have the legal power to make economic agents conform to regulations, the role of governments in regulation is significant, meaning while the ambiguities in legal and policy frame works could effect the operational environment of MFIs as well, for instance in Russia the ambiguous and uncertain policy environment had left MFIs vulnerable to regulatory discretion in the interpretation of the legal basis for lending activities [27]. The Indian experience offers a solution to this situation through dialogue dominated approach between NGOs and government agency in developing an appropriate regulation frame work. According to the study of $[32,10]$ they found out this approach is cautiously taking step in the right direction and creating a space for MFIs to grow further, which is very different from the passive attitude followed by the government toward microfinance sectors over the years. Even though this approach takes time to evolve, it provides opportunity for MFI's to set common priorities for the development of the sectors, particularly when the countries have different operating models. Normally both donors and governments expect that regulations will speed up the emergence of sustainable MFIs. However, the process of integrating Microfinance sector $[5,10]$ because of this variety in the type of MFIs it has been suggested that institutions be fitted into tired structure which clearly defines how the types of instutions are regulated and by whom [21]. The advantages of that approach are to provide opportunity and incentives for MFIs to graduate between tiers and that it creates appropriate regulatory requirements for different types of institutions.

The tiered approach has benefited the development of sustainable microfinance in the Philippines and Ghana by clearly identifying pathways for MFIs to become legitimate institutions and gain access to financial resources from comercial markets [8]. In Ghana, the tiered approach has led to the growth of different types of MFIs. Also it has permitted the easy entry of institutions with weak management and internal control. This experience 
demostrates the difficulty in balancing entry and innovation on the one hand, and appropriate regulatory capacity on the other hand [29, 10]. According to the study of [28] it shows if the tiers are not defined properly, this could lead to regulatory arbitrage, overlap and ambiguity. [3]. There is a strong perception that regulation in a tiered approach must in corporate the basic features of the sectors, such as management capacities, the nature of the clients and transactions volume, diversity among instution types and to be consistent with the overall financial sector framework.

\section{Literature Review}

A difficulty on loan repayment is a continuous handicap to many Microfinance Institutions' customers. Many researchers have been done to address the problem. A study done by $[22,31]$ has shown some of the factors that default loan repayment to be: lack of adequate credit collection rate by the MFIs, poor information and communication network for assessment of debtors, lack of proper follow up and supervision, and correction, lack of business education to the Small and Medium Enterprises (SMEs) before loans are extended, debtors' mismanagement of funds borrowed to activities that do not have immediate returns at all and higher interest rates becoming the major burden to debtors that delay the repayment of the principal or make it impossible. [1] explains that one of the determinants for investment spending includes expectation about future production cost. However, higher interest charges on borrowings increase the cost and discourage investment. When in deciding whether to undertake investment, firms not only look at the expected rates of return, but also at the cost of capital which is the rates of interest on the money used. Interest rates, therefore, affect many business decisions due to a rise in interest rates hindering the growth and development of SMEs, which weaken debtor's ability to pay back the principal amount of borrowed funds plus interest [25].

In developing countries like Tanzania with inflation rates, interest rate is also high. The higher the interest rate and default risk, the higher the interest charged on borrowed funds. So in Tanzania, Microfinance Institutions (MFIs) operate in an environment where they face high inflation and high default risk, they must have high interest rate in order to remain effective in lending industry [7]. MFI's clients are willing to pay such high interest rates in order to assure longterm access to unsecured micro loans. [15] which identified the difficulties of small firms: "they have little knowledge of sources of finance and that interest rates asked are higher than for larger established firms and security for loan may be inadequate, given the stringent demands of lenders". Government interventions associated with low interest ceilings, are also associated with negative real deposits by borrowers together with other negative consequences such as low repayment rates. These things discourage banks from lending to SMEs since they are unattractive borrowers. Consequently the real credit contracts of banks are offered only to the large enterprises, which are more likely to access credits. The SMEs are effectively crowded out from formal credit market and forced to rely on self-financing and informal credit sources that are insufficient and more expensive in some cases [31]. In recent years micro-finance has transformed from an experimental alternative to formal and informal sources of credit, and has become a model for lending programs to the poor and a tool for poverty alleviation. Microfinance has allowed credit to the poor, beyond the traditional financial frontiers as lack of collateralizable assets, and overcome collateralizable assets problem by group lending in tight-knit communities. Most Microfinance Institutions (MFIs), employ the solidarity group-lending model such as Grameen Model that originated in Bangladesh. This model provides advantage to MFIs to minimize risks [18]. It enables many MFIs to decrease transaction costs; however, studies indicate that there is a problem of repayment when this model is used [4]. Moreover, [27] argued that group lending institutions have better repayment than individual lending programs in good years but worse repayment in years with some type crisis. That is, if one or more members of the group encounter repayment difficulties the entire group often collapses.

The government of Tanzania has made its effort on this problem. According to a report by [2] the Bank of Tanzania continues to promote efficiency of the financial sector in order to make interest rates liberalization. The implementation of the ongoing second-generation financial sector reforms are aimed at removing bottlenecks in lending market and improves access efficiency to financial services. It is expected that as the efficiency increases in the financial system, and lending risks to the private sector are minimized, the interest applied on loans will reflect the opportunity cost of funds in the economy. Based on that, one aspect that influences the intensity of interest rates in MFIs in Tanzania is the performance of the Bank of Tanzania (BOT). In demanding to avoid substantial swings in the business cycle, the BOT regulates short-term interest rates. It lifts up interest rates to slow down a cost-cutting measure (financial system) that is increasing too rapidly and lowers them when the financial system is heading for a depression. Rising and falling interest rates will directly have an effect on consumer and individual economic decisions. Increasing interest rates create saving moderately more attractive and borrowing relatively more expensive. Diminishing interest rates have the reverse effect. Subsequently, the consequence of an interest rate going up or going down will depend on whether you are an investor or a borrower. The intensity of interest rates has an undeviating consequence on a customer's aptitude to reimburse a loan. For example, [22, 17] declare that once interest rates are low, buyers are agreeable to borrow for the reason that they stumble on the easiest way to repay their debt. At that time when interest rates are high, customers are unwilling to borrow because of higher repayments on loans. Several customers may even find it difficult to achieve their existing loan repayments, particularly if interest rates boost more rapidly than the increase in a client's expenses. If interest rates go up roughly 
and keep on top level (high) for a long period, some customers will collapse to pay back on their loans.

\section{Research Methodology}

We adopted descriptive assessment techniques. In these techniques the data is collected through interviewing or administering a questionnaire to a sample of individuals [14]. The research sampling was 400 respondents which employed simple random sampling and stratified random sampling under probabilistic sampling and non-probabilistic samples by employing purposive sampling [16]. The clients and staffs of MFIs were the targeted population which provided useful information about interest rates and loan repayment through analyzing the different parameters such as Interest Rates, Multiple loan, and Business capacity. Furthermore SPSS software was used for data analysis of the different variables.

\section{Results and Discussion}

The study sought to establish the impact of interest rate on loan repayment on MFIs in Tanzania. According to analysis made $36 \%$ of respondents claim the loan defaulted due to high interest rate while $34.6 \%$ say due to higher loan level as compared to business capacity and $25.6 \%$ say due to multiple loans. After general observations of the presented responses, the first hypothesis had the intention of testing if higher interest rate has an impact on loan repayment. It was hypothesized that: $H_{00}$ : There is no significant relationship between interest rate charged on loan and loan repayment. $H_{11}$ : There is a significant relationship between interest rate charged on loan and loan repayment.

Table 1. Chi-Square Tests for the Relationship between Interest rates and Loan Default in MFI's.

\begin{tabular}{ll}
\hline Test Statistics & \\
\hline & Relationship between Interest rates and loan defaults in \\
& MFI's \\
Chi-Square & $27.222^{\mathrm{a}}$ \\
Df & 3 \\
Asymp. Sig. & .000 \\
\hline
\end{tabular}

a. 0 cells $(0.0 \%)$ have expected frequencies less than 5 . The minimum expected cell frequency is 54.0.

From the computed chi- square value 27.222 at 3 degrees of freedom found there is significant relationship between interest rate charged on loan and loan repayment. Since the computed p- value 0.000 was smaller than 0.01 at $99 \%$ confidence level, this therefore means that there was high extent of loan default when a client takes a higher loan than the capacity of its business. That causes the burden for the principal and interest amounts repayment to become large when the individual business capacity was low and the client acquired higher loan levels.

The involvement of business capacity with level of loan and interest charged indicated that $51.4 \%$ of PRIDE clients measures the capacity of their businesses to repay the loan plus interest before applying for a certain level of loan, while for SEDA clients is only $48.6 \%$ measure the capacity of the business before loan application. The second hypothesis had an intention of testing whether there is any significant relationship between the capacity of business to repay the loan and loan repayment. It was hypothesized that: $H_{21}$ : There is no significant relationship between clients' business capacity and loan repayment. $H_{22}$ : There is a significant relationship between clients' business capacity and loan repayment.

Table 2. Chi-Square Tests for the Relationship between Clients'Business Capacity and Loan Default in MFIs.

\begin{tabular}{ll}
\hline Test Statistics & \\
\hline & $\begin{array}{l}\text { Relationship between client business capacity and loan } \\
\text { default in MFI }\end{array}$ \\
Chi-Square & $106.194^{\mathrm{a}}$ \\
Df & 2 \\
Asymp. Sig. & .000 \\
\hline
\end{tabular}

a. 0 cells $(0.0 \%)$ have expected frequencies less than 5 . The minimum expected cell frequency is 72.0 .

This is supported by the estimated chi-square value 106.194 at 2 degrees of freedom and p- value 0.000 which was less than 0.01 at $99 \%$ confidence level. This therefore means that 50 percent of the total clients go for higher loans without measuring if the amount of loan they seek is viable to be repaid by their businesses. This brings repayment problems due to higher percentage of clients taken loan without considering the capabilities of their business to repay the loan plus interest. Therefore, it is concluded that, there is enough statistical evidence to prove that there was a relationship between clients' business capacity and loan repayment.

According to the client member's participation in interview, they argued that, one of the causes of loan default was multiple loans while for SEDA clients 30 percent claimed the same. Moreover, 70 percent of PRIDE staffs experience the cause of loan default to be multiple loans while for SEDA staffs only 30 percent experience it to be the cause of loan default. This indicates that the negative impact of multiple loans exists more in PRIDE as compared to SEDA. This was a result of PRIDE clients being more transparent to their Credit Officers as there are many known cases of individuals who obtained loan from both MFIs. The researcher discovered a problem of information transparency between clients and credit officers. Clients hide information about fellow members with multiple loans believing their fellow was obtaining loan from the other institutions so as to repay the one in the institution they are together. The third hypothesis had the intention of testing if clients who acquire more than one loan within the same or different MFIs at the same period of time have any relationship with MFIs' loan repayments. It was hypothesized that: $H_{31}$ : There is no significant relationship between multiple loans and loan repayment. $H_{32}$ : There is a significant relationship between multiple loans and loan repayment. 
Table 3. Chi-Square Tests for the Relationship between Multiple Loans and Loan Default in MFI's.

\begin{tabular}{ll}
\hline Test Statistics & \\
\hline & $\begin{array}{l}\text { To what extent are the causes of loan default in your } \\
\text { institution }\end{array}$ \\
Chi-Square & $10.985^{\mathrm{a}}$ \\
Df & 4 \\
Asymp. Sig. & .027 \\
\hline
\end{tabular}

a. 0 cells $(0.0 \%)$ have expected frequencies less than 5 . The minimum expected cell frequency is 27.2 .

The analysis of relationship between multiple loans and loan default is not significant. From computed chi-square value 10,985 at 4 degrees of freedom, p-value 0.027 was greater than 0.01 at $99 \%$ confidence level as shown in table 3 above. This therefore, shows there is not significant relationship between multiple loans and loan repayments in MFIs, taking loans within the same MFI or different MFIs is not directly leading to problems in loan repayment.

\section{Conclusion and Recommendation}

The general objectives of the study was to identify the causes of interest charged on loan repayment to Microfinance Institutions in Tanzania, the specific objectives were to assess the business capacity of Micro-finance Institution's clients to repay loan, to examine if multiple loans contribute to difficulty on loan repayment and finally to determine the relationship between interests charged on loan and loan repayment. The consequence shows that there is strong negative correlation between multiple loans and loan repayment in MFIs. It means that taking multiple loans within the same MFI or different MFIs is not directly leading to problems in loan repayment, while business capacity with level of loan and interest charged and the extent of higher interest rates than business capacity to cause loan default has significant relationship with interest rate.

The study recommended that in order for any business to meet its obligations, the business owner should focus on the level of the business capacity and the level of the loan proposed to be taken as well as making the comparison of the daily business revenues operation and not the capital of the business initiatives. Therefore, the microfinance client must focus on the future needs for accessibility of good business operations, once the business collapses it need to seek another alternative for solving the problems of paying the loans to the micro financial institutions, but taking another loan to the different micro financial institutions to repay the loan increases the interest burden. Further empirical investigation is needed on the impact of interest rates that MFIs charge excessive and too high for MSME operations enhancing Challenges and Opportunity.

\section{References}

[1] Archer, M (1988), Introduction to Economics, 4th Ed, Maurice Archer Books, Canada.
[2] Bank of Tanzania (2007), Monetary Policy Statement, the Midterm Review.

[3] Berenbach, S., and Churchill, C. (1997). Regulation and supervision of microfinance institutions: Experience from Latin America, Asia and Africa. Washington, DC: USAID.

[4] Chijoriga, M. M (2000), "Recital and Sustainability of Micro financing Institutions in Tanzania", Paper presented at the $3^{\text {rd }}$ International Conference on Africa Entrepreneurship and Small Business Development $28^{\text {th }}-29^{\text {th }}$ September, 1999, Journal of Development Studies, Austria, Vol 16/3.

[5] Christen R. P., and Rosenberg, R. (2000). The rush to regulate: Legal frame work for microfinance (Occasional Paper No. 4). Washington DC: CGAP.

[6] Daley-Harris, S. (2007), Circumstances of the Microcredit Meeting Operation Report 2007, Washington, DC: Microcredit Meeting Campaign.

[7] Funkor G. (2000). "Private Business Concerns. About Interest Rates". Banking and Graphic Newspaper, Accra, Ghana, October 18, p. 11.

[8] Gallardo, J. (2002). A Structure Exertion for Adaptable Micro Financial Intermediaries: The experience in Ghana and Philippines (Policy research working paper (No. 2755). Washington DC: World Bank.

[9] Gulli, H. (1998), Microfinance and poverty, Washington, DC: Inter-American Development Bank.

[10] Hulme, D and Arun, T. (2009), 'Microfinance A reader' Routledge Studies in Development Economics, New York.

[11] Hulme, D and Moore, K. (2008), 'Assisting the poorest in Bangladesh: Learning from BRAC's "Targeting the Ultrapoor" Programme', in A. Barrientos and D. Hulme (Eds), Community Safeguard in Favour of the Poor and Poorest: Awareness, Guidelines and Performance, London: Routledge.

[12] Hulme, D. And Mosley, P (1996), Finance along Poverty, London: Routledge.

[13] Johnson,. S and B. Rogaly (1997), 'Microfinance and Poverty Reduction', Oxfam Poverty Guidelines, Oxford.

[14] Kerlinger, F. N (1973), Institution of Behaviour Investigation, New York: Holt Rinehart and Winston.

[15] Knott G. (1991), Financial Management, The Macmillan Journalists Ltd".

[16] Kothari, R. (1990), Research Techniques (Design and Practice), $2^{\text {nd }}$ Version, New Age International, New Delhi

[17] Lascelles, D. (2008), ' Microfinance Banana Crust 2008: Risk in a deafening Industry, middle for the study of Financial modernization (CSFI), New York. Accessible http://www.microfinancegateway.org/files/47464_file_CSFI_ Microfinance_FINAL.pdf [Accessed January 2015 at 07:15PM]

[18] Ledgerwood, J (1999), Microfinance Handbook, An institutional and Financial Perspective, The World Bank, Washington, D. C".

[19] Lipton, M., A. deHaan and S. Yaqub (1997), 'Credit and employment for the poor', politica Internazionale, 5 Sep-Oct, 153-66. 
[20] Martin, I and S. Sinha (1998), 'Informal credit transaction of microcredit borrowers', IDS Bulletin, 29 (4).

[21] Meagher, P. (2002) Microfinance regulation in south Africa: A comparative perspective. Development Bulletin, 57, 48-52.

[22] Monyo, J. M (2004), "Causes Of Debt Collection Problems. In Microfinance Organizations: Case Of Muhembe Business Care", Journal Of The Institute Of Accountancy Arusha, Tanzania Vol 1/2, 1-2”.

[23] Morduch, J. (1999). 'The microfinance promise', Journal of Economic Literature, XXXVII (December), 1569-614.

[24] Morduch, J. (2000). 'The microfinance schism', Word development, 28 (4), 617-29.

[25] Oyejide, T. A (1993), Financial Liberalization under structure adjustment and its implications for financing small-scale and microenterprises in Nigeria.

[26] Rutherford, S. (1999), The Poor and their Money, New Delhi: Oxford University Press.

[27] Safavian, M. S., Graham, D. H,. Gonzalez-Vega, C., and Whelan, D. (2000). The state of microfinance activity and regulation in Russia. Small Enterprises Development, 11, 4.
[28] Staschen, S. (2003). Regulatory Requirements for Microfinance: A comparison of legal frame works in 11 countries word wide. Eschborn: GTZ.

[29] Steel, William, E., Ernest, A., Hemala, H., Nissanke, M. (1997). "Informal Financial Markets under Liberalization in Four African Countries.” World Development 25 (5): 817-830.

[30] Stieglitz, J. (1998), Additional Instruments and Broader Aspiration: Affecting Toward the Post Washing Consensus', Helsinki: 1998 WIDER Annual Lecture January 7.

[31] Temu, S.(1998), The Impact Of Financial Institutions Reforms On Small And Micro Enterprises Financing In Tanzania: Business Management Review, December 1998, Vol. 5/2, Dar es salaam University Press, Dar es salaam pp. 56-78.

[32] Titus. M. (2000). Building the Regulatory Frame Work for Microfinance in India. Small Enterprise Development, 11. 4

[33] Wright, G. (2000). Microfinance System: Designing Quality Financial Services for the poor. London: Zed Book. 